E-JURNAL EKONOMI DAN BISNIS UNIVERSITAS UDAYANA
Available online at https://ojs.unud.ac.id/index.php/EEB/index
Vol. 11 No.01, Januari 2022, pages: $87-96$
e-ISSN: $2337-3067$

\title{
PENGARUH CITRA MEREK, KESADARAN MEREK, DAN PEMASARAN DIGITAL TERHADAP KEPUTUSAN PEMBELIAN AMDK AQUA
}

\author{
Anak Agung Inta Setya Dewi ${ }^{1}$ Ni Luh Putu Indiani ${ }^{2}$
}

Article history:

Submitted: 7 Juli 2021

Revised: 16Oktober 2021

Accepted: 29 Oktober 2021

\section{Keywords:}

Merek Image;

Merek Awarenes;

Pemasaran Digital;

Purchase Decision;

\section{Kata Kunci:}

Citra merek;

Kesadaran merek;

Pemasaran digital;

Keputusan pembelian

\section{Koresponding:}

Fakultas Ekonomi dan Bisnis

Universitas Warmadewa,

Bali, Indonesia

Email:indi_arca@yahoo.com

\section{Abstract}

There are a number of bottled drinking water (AMDK) mereks in the market, AQUA as a pioneer of AMDK has succeeded in becoming the market leader in the industry. This raises interest in analyzing the facto rs that drive AQUA to become AMDK marketleader in Indonesia. This study aims to analyze the influence of merek image, merek awareness, and pemasaran digital on consumers'decision to purchase AQUA in Denpasar. The population in this study is Denpasar citizens who have ever con sumed bottled drinking water. The sample used was 100 people. Data were collected using survey method with a questionnaire. Multiple linear regression analysis technique was used to test the effect of independent variable on dependent variable. This study found that merek image and pemasaran digital have a positive and significant impact on purchase decision, but merek awareness has a positive and insignificant impact on purchase decision. To improve merek image, AQUA needs to have a distinctive character, unique and superior to its competitors. To improve the performance of the pemasaran digital aspect, AQUA needs to develop marketing in digitalmedia, suchas in its official website, social media, search engine, and implement affiliate marketing.

Abstrak
Terdapat sejumlah merek air minum dalam kemasan (AMDK) di
pasaran, AQUA seba gai pelopor AMDK telah berhasilmenjadi pemimpin
pasar di industri. Hal ini menimbulkan ketertarikan unt uk menganalisis
faktor-faktor yang mendorong AQUA menjadi pemimpin pasar AMDK di
Indonesia. Penelitian ini bertujuan menganalisis penga ruh citra merek,
kesa daranmerek, dan pemasaran digitalterhadap keputu san pembelian
AQUA di kota Denpasar. Populasi dalam penelitian iniadalah mas yarakat
kota Denpasar yang pernah mengkonsumsi AMDK. Sampelyang digunakan
adalah sebanyak 100 orang. Pengumpulan data mempergunakan metode
survey dengan kuesioner. Teknik analisis regresi linier berganda digunakan
untuk menguji pengaruh variabel bebas terhadap variabeldependen. Hasil
penelitian ini menemukan bahwa citra merek dan pema saran digital
berpengaruh positif dan signifikan terhadapkeputusan pembelia n, namun
kesadaran merek berpengaruh positif dan tidak signifikan terhadap
keputusan pembelian. Untuk meningkatkan citra merek, AQUA perlu
memiliki karakter yang khas, memiliki keunikan dan keunggulan
dibandingkankompetitornya. Untuk meningkatkan kinerja a spekpemasaran
digital, AQUA perlu mengembangkan pemasaran di media digital y aitu
pada websiteresmi, media sosial, searchengine, danmelakukan affiliate
marketing.

Fakultas Ekonomidan Bisnis Universitas Warmadewa, Bali, Indonesia ${ }^{1}$

Email: intasetyadewi09@gmail.com 


\section{PENDAHULUAN}

Maraknya pembangunan di daerah perkotaan ini menyebabkan lahan terbuka hijau semakin berkurang. Akibatnya air bersih layak konsumsi semakin sulit didapatkan oleh masyarakat. Permasalahan ini membuka celah lebar bagi perusahaan untuk menjadikannya sebagai peluang bisnis. Penyediaan Air Minum Dalam Kemasan (AMDK), menjadi pilihan utama bagi masyarakat sebagai solusi untuk tetap bisa mengkonsumsi air minum dengan kualitas baik. Beragam merek kini telah hadir meramaikan industri AMDK, sehingga konsumen dihadapkan pada berbagai pilihan. Disinilah tantangan bagi para pemasar untuk memenangkan pangsa pasar. Terdapat sejumlah merek AMDK yang dengan mudah ditemukan oleh konsumen di pusat perbelanjaan diantaranya: Ades, AQUA, Le Mineral, Vit, Nestle Pure Life, Cleo, dsb. Berbagai keunggulan atau jenis produk yang ditawarkan oleh setiap merek tentunya menjadi suatu daya saing agar mampu bersaing dengan kompetitor sejenis. Begitu banyaknya produk sejenis di pasaran dengan berbagai merek tentunya membuat konsumen dihadapkan pada banyak alternatif pilihan sebelum membuat keputusan pembelian. Top Brand Award (TBA) oleh Frontier Consulting Group menjadi acuan bagi konsumen dalam memilih merek. Berikut data Top Brand Index (TBI) dalam industri AMDK selama kurun waktu lima tahun.

Tabel 1.

Data Top Brand Index AMDK Tahun 2015- 2019

\begin{tabular}{cccccc}
\hline Merek & $\mathbf{2 0 1 5}$ & $\mathbf{2 0 1 6}$ & $\mathbf{2 0 1 7}$ & $\mathbf{2 0 1 8}$ & $\mathbf{2 0 1 9}$ \\
\hline AQUA & $75,9 \%$ & $73,4 \%$ & $73,3 \%$ & $63,9 \%$ & $61,0 \%$ \\
Ades & $2,6 \%$ & $3,4 \%$ & $4,1 \%$ & $7,6 \%$ & $6,0 \%$ \\
Club & $5,0 \%$ & $3,4 \%$ & $4,5 \%$ & $3,4 \%$ & $5,1 \%$ \\
Le mineral & - & - & - & - & $5,0 \%$ \\
Cleo & - & $2,0 \%$ & - & $2,7 \%$ & $4,7 \%$ \\
Tang & - & $1,4 \%$ & $1,8 \%$ & $3,2 \%$ & - \\
VIT & - & - & $6,1 \%$ & - & - \\
\hline
\end{tabular}

Sumber: TopBrandAward, 2020

Berdasarkan data pada Tabel 1 dapat dilihat bahwa AQUA menempati peringkat pertama TBI selama lima tahun berturut-turut secara konsisten. Namun, jika dilihat dari persentase yang diperoleh setiap tahunnya, merek AQUA mengalami penurunan. Pada tahun 2015, AQUA mendapat persentase TBI sebesar 75,9\%. Kemudian pada tahun 2016, AQUA mengalami penurunan menjadi 73,4\%. AQUA mengalami penurunan lagi pada tahun 2017 sebanyak 0,1\%. Di tahun 2018, AQUA mengalami penurunan yang signifikan menjadi 63,9\%. Pada tahun 2019 AQUA kembali mengalami penurunan menjadi 61,0\&. Dapat diambil simpulan dari tabel tersebut bahwa merek AMDK AQUA lebih unggul diantara merek lainnya. Walaupun mengalami penurunan persentase setiap tahunnya, AQUA telah berhasil menjadi pemimpin pasar di industri AMDK.

AQUA menjadi salah satu merek AMDK yang menerapakan pemasaran digital dalam kegiatan pemasarannya. Kemunculan AQUA di beberapa platform digital, menjadikan merek ini lebih dikenal oleh konsumen. Pada data index digital popular AMDK ditemukan beberapa merek yang cukup familiar di kalangan masyarakat. AQUA memimpin dengan persentase 29,08\%, dapat diklaim bahwa data pencarian terbanyak yang dicari oleh konsumen yaitu AMDK merek AQUA dibandingkan merek lainnya (InfoBrand, 2020). 
Tabel 2.

Data Index Digital Popular AMDK Tahun 2019

\begin{tabular}{cc}
\hline MEREK & Index Digital Popular \\
\hline AQUA & $29,08 \%$ \\
VIT & $23,76 \%$ \\
Cleo & $21,79 \%$ \\
\hline
\end{tabular}

Sumber: InfoBrand, 2020

Berdasarkan pada Tabel 1 dan Tabel 2, dapat dilihat bahwa AQUA memimpin pangsa pasar AMDK di Indonesia. Ini merupakan indikasi bahwa konsumen lebih memilih AQUA dibandingkan AMDK merek lainnya. AQUA yang selalu menjadi pemimpin pasar di industri AMDK tentunya sangat bergantung pada keputusan pembelian oleh konsumen. Hal ini menimbulkan ketertarikan untuk menganalisis pengaruh kesadaran merek, citra merek, dan pemasaran digital terhadap keputusan konsumen untuk membeli merk AQUA. Penelitian ini penting dilakukan karena hasil penelitian dapat menjadi benchmark bagi pelaku ritel dalam menyusun strategi branding dan pemasaran digital untuk mendorong keputusan pembelian konsumen. Di samping itu, terdapat celah penelitian yang ingin diisi melalui penelitian ini. Penelitian sebelumnya menganalisis pengaruh pemasaran digital terhadap keputusan pembelian dengan ruang lingkup pemasaran digital yang sempit yaitu secara spesifik pada 1) pemasaran media sosial oleh (Wibowo et al., 2021); (Pucci et al., 2019); (Duffett, 2015); (Irshad \& Ahmad, 2019); (Abdul Hafeez et al., 2017); (Mohamad et al., 2018); (Almohaimmeed, 2019); (Raji et al., 2019); (Shin \& Choi, 2021); 2) pembentukan komunitas online (Tiruwa et al., 2016); 3) iklan pada aplikasi berbasis internet (Maseeh et al., 2020); 4) iklan berbasis lokasi (Gazley et al., 2015); 5) pemasaran melalui perangkat seluler (Chinomona \& Sandada, 2013). Pada penelitian ini, variabel pemasaran digital mencakup ruang lingkup yang lebih luas meliputi: pemasaran media sosial, pemasaran melalui website termasuk search engine dan web banner, dan affiliate marketing. Dengan ruang lingkup yang lebih luas, penelitian ini menggambarkan pemasaran digital secara lebih komprehensif.

Keputusan pembelian adalah proses pengintegrasian yang mengkombinasikan pengetahuan untuk mengevaluasi dua atau lebih alternatif dan memilih salah satu diantaranya(Peter \& Olson, 2000). Perilaku konsumen dalam melakukan pembelian dapat berbeda-beda karena beberapa faktor yang mempengaruhinya baik pengaruh dari diri konsumen itu sendiri (faktor internal) maupun pengaruh dari luar (faktor eksternal). (Andrian, 2019) mengemukakan bahwa terdapat empat indikator keputusan pembelian yaitu: 1) Minat transaksional, yaitu kecenderungan membeli produk; 2) Minat referensial, yaitu kecenderungan mendorong orang lain untuk membeli produk tersebut; 3) Minat preferensial, yaitu menunjukan perilaku yang memiliki preferensi umum pada produk tersebut. Preferensi ini dapat berubah apabila terjadi perubahan pada produk preferensinya; 4) Minat eksploratif, yaitu menunjukan perilaku seseorang yang selalu mencari informasi mengenai produk yang diminati dan mencari informasi lain yang mendukung sifat positif dari produk tersebut.

Dari kajian literatur ditemukan bahwa citra merek merupakan faktor yang kuat mempengaruhi keputusan pembelian. Citra merek merupakan persepsi dan keyakinan konsumen yang tercermin dalam asosiasi dalam memori konsumen (Kotler \& Keller, 2008). Citra merek adalah gambaran atau kesan yang ditimbulkan suatu produk di dalam pikiran konsumen. Menurut (Rahman, 2010) citra merek merupakan persepsi konsumen yang muncul ketika mengingat sebuah produk tertentu. Merek yang kuat merupakan aspek penting bagi setiap perusahaan karena memberikan berbagai keunggulan, seperti persepsi kualitas yang baik, loyalitas merek yang lebih tinggi, marjin keuntungan yang lebih besar, dan peluang tambahan untuk perluasan merek. Citra merek yang positif dapat mendorong 
keputusan pembelian seperti yang ditemukan dalam sejumlah penelitian. (Fure et al., 2015) menemukan bahwa terdapat pengaruh citra merek yang positif dan signifikan terhadap keputusan pembelian J.Co di Manado. Penelitian serupa dilakukan oleh (Pulukadang et al., 2019) menemukan bahwa citra merek berpengaruh positif dan signifikan terhadap keputusan pembelian Herbalife di kota Manado. Pada penelitian yang dilakukan oleh (Fariha, 2018) mengenai pengaruh citra merek terhadap keputusan pembelian Chattime pada remaja di Kota Palembang, menemukan pengaruh positif dan signifikan. (Simamora \& Kusmiyati, 2017) menemukan bahwa terdapat pengaruh yang positif dan signifikan antara variabel citra merek terhadap keputusan pembelian Teh Botol Sosro di Jakarta. Dalam penelitian yang dilakukan oleh (Yanti \& Sukotjo, 2016), menemukan bahwa citra merek berpengaruh secara parsial dan signifikan terhadap keputusan pembelian AQUA di kota Surabaya. Citra merek yang kuat dapat meningkatkan kepercayaan konsumen terhadap merek tersebut, hal ini mendorong minat beli konsumen terhadap merek tersebut. Dari kajian empiris tersebut dapat dirumuskan hipotesis sebagai berikut: H1: Citra merek berpengaruh positif dan signifikan terhadap keputusan pembelian.

Di samping citra merek, faktor lain yang menentukan keputusan pembelian yaitu kesadaran merek. Kesadaran merek merupakan tingkat penerimaan awal seseorang ketika melihat atau mendengar suatu informasi tentang produk beserta mereknya (Surachman, 2008). Kesadaran merek dapat diartikan sebagai kemampuan pelanggan untuk mengenali atau mengingat kembali sebuah merek dan mengaitkannya dengan satu kategori produk tertentu (Suciningtyas, 2012). Dengan demikian, seorang pelanggan yang memiliki kesadaran terhadap sebuah merek secara otomatis mampu menguraikan elemen-elemen merek tanpa harus dibantu (Cahyani \& Sutrasmawati, 2016). Perusahaan dengan kesadaran merek yang tinggi dapat lebih mudah memperkenalkan produk baru dan memasuki pasar baru. Semakin tinggi kesadaran konsumen terhadap suatu merek maka semakin tinggi kecenderungan untuk melakukan pembelian produk. Pernyataan ini didukung oleh sejumlah penelitian: (Ekawati \& Aryadirda, 2015) menemukan bahwa kesadaran merek mempengaruhi keputusan pembelian konsumen terhadap produk Planet Popcorn di Jakarta. Penelitian yang dilakukan oleh (Sudarso, 2018) menemukan bahwa kesadaran merek berpengaruh secara positif dan signifikan terhadap keputusan konsumen untuk membeli produk CV. Panda Bakery. Kembali ditegaskan dalam penelitian yang dilakukan oleh (Ronoprasetyo, 2018) bahwa terdapat pengaruh positif dan signifikan kesadaran merek terhadap pembelian produk Bjong Ngopi di Sleman. Selain itu, penelitian yang dilakukan oleh (Apriliya, 2018) juga menunjukan bahwa kesadaran merek berpengaruh positif dan signifikan terhadap keputusan pembelian konsumen terhadap produk Mie Akhirat di Surabaya. Penelitian yang dilakukan oleh (Ghealita, 2015) menemukan bahwa kesadaran merek berpengaruh signifikan terhadap keputusan pembelian AMDK merek AQUA pada masyarakat di Kota Bandung. Kesadaran merek yang tertanam kuat di benak konsumen menjadikan merek tersebut berada pada tingkatan top of mind, faktor ini sangat memungkinkan untuk mempengaruhi pertimbangan konsumen dalam menentukan keputusan pembelian. Berdasarkan uraian tersebut dapat dirumuskan hipotesis sebagai berikut: H2: Kesadaran merek berpengaruh positif dan signifikan terhadap keputusan pembelian.

Keputusan pembelian juga dipengaruhi oleh aktivitas pemasaran yang dilakukan oleh perusahaan. Di era modern ini, pemasaran digital menjadi trend baru dalam aktivitas pemasaran. Sejumlah pemasar telah menerapkan pemasaran digital pada aktivitas pemasarannya. Platform digital adalah salah satu media yang saat ini sedang diminati oleh masyarakat untuk mendukung berbagai kegiatan yang dilakukan (Saputra \& Ardani, 2020), salah satunya adalah aktivitas berbelanja. Perdagangan ritel online di Indonesia mengalami perkembangan pesat pada satu dekade terakhir 
(Indiani \& Fahik, 2020). Pertumbuhan ini tidak lepas dari pengaruh aktivitas pemasaran digital yang dilakukan oleh pemasar. Pemasaran digital adalah penggunaan internet dan teknologi interaktif lain untuk menyampaikan informasi kepada konsumen yang telah teridentifikasi (Sam, 2018). Pemasaran internet atau digital dapat melalui website, search engine marketing, web banner, situs media sosial, viral marketing, e-mail marketing dan affiliate marketing. Pemasaran digital sebagai salah satu strategi bisnis dalam pemasaran jika dilakukan dengan tepat tentunya memberikan dampak yang positif bagi kemajuan bisnis, khususnya dalam mempengaruhi keputusan pembelian konsumen. Pernyataan ini didukung oleh sejumlah penelitian: Saputra \& Ardani (2020) menemukan bahwa pemasaran digital berpangaruh secara positif dan signifikan terhadap keputusan pembelian konsumen terhadap produk PT. Pegadaian Wilayah VII Denpasar. Penelitian yang dilakukan oleh Batu et al. (2019) menegaskan bahwa terdapat pengaruh positif pemasaran digital terhadap keputusan pembelian online. Pratama (2017) menemukan bahwa pemasaran digital berpengaruh terhadap keputusan pembelian konsumen di Tokopedia. Penelitian yang dilakukan oleh Mewoh et al. (2019) mengemukakan bahwa pemasaran digital berpengaruh positif dan signifikan terhadap keputusan pembelian. Dari kajian empiris tersebut dapat dirumuskan hipotesis sebagai berikut: H3: Pemasaran digital berpengaruh positif dan signifikan terhadap keputusan pembelian. Kerangka konseptual penelitian digambarkan sebagai berikut:

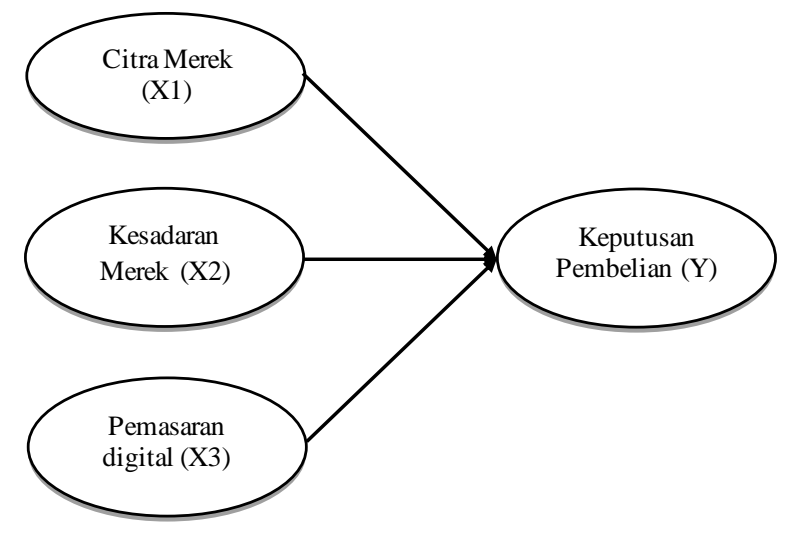

\section{Gambar 1. \\ Kerangka Konseptual Penelitian}

\section{METODE PENELITIAN}

Kota Denpasar dipilih sebagai lokasi penelitian karena Denpasar merupakan kota dengan wilayah padat penduduk di Bali, selain itu pusat aktivitas bisnis dan perekonomian terletak di kota Denpasar. Dengan gaya hidup masyarakat yang modern serta aktivitas yang padat membuat masyarakat lebih menyukai segala sesuatu yang bersifat praktis, hal ini membuka celah lebar bagi perusahaan AMDK untuk mengembangkan usahanya. Populasi yang digunakan dalam penelitian ini yaitu seluruh masyarakat kota Denpasar sebanyak 1.454.400 orang. Jumlah sampel dalam penelitian ini yaitu sebanyak 100 sampel, diperoleh berdasarkan perhitungan dengan rumus Slovin pada taraf keyakinan $10 \%(0,01)$. 
Perhitungan jumlah sampel:

$$
\begin{aligned}
\mathrm{n} & =\frac{\mathrm{N}}{1+\mathrm{Ne}^{2}} \\
& =\frac{1.454 .400}{\left(1+1.454 .400(0,1)^{2}\right)} \\
\mathrm{n} & =\quad \frac{99,99(\text { dibulatkan menjadi 100) }}{}
\end{aligned}
$$

Penelitian ini menggunakan teknik nonprobability sampling yaitu teknik pengambilan sampel dengan tidak memberi kesempatan yang sama pada setiap unsur atau anggota populasi untuk menjadi sampel. Teknik nonprobability sampling yang dipilih adalah metode purposive sampling yaitu teknik pengambilan sampel dengan pertimbangan tertentu. Kriteria sampel yaitu masyarakat kota Denpasar yang pernah mengkonsumsi AMDK. Kriteria ini ditetapkan agar responden dapat memberikan respon yang akurat terhadap pernyataan kuesioner.

Metode pengumpulan data yang digunakan dalam penelitian ini yaitu metode survey menggunakan kuisioner. Setiap butir pernyataan diukur dengan skala Likert. Teknik analisis data yang digunakan yaitu analisis regresi linier berganda untuk mengukur pengaruh variabel bebas terhadap variabel dependen.

\section{HASIL DAN PEMBAHASAN}

Hasil uji validitas ditampilkan pada Tabel 3 yang menunjukkan bahwa seluruh koefisien korelasi dari indikator variabel yang diuji nilainya lebih besar dari 0,30 . Hal ini menunjukkan bahwa seluruh indikator yang terdapat pada penelitian ini terbukti valid.

\begin{tabular}{|c|c|c|c|c|}
\hline Variabel & Kode & Item & Korelasi & Keterangan \\
\hline \multirow{5}{*}{ Citra Merek } & $\mathrm{X} 1.1$ & Mengenali logo Aqua & 0,358 & Valid \\
\hline & $\mathrm{X} 1.2$ & Aqua memiliki karakter khas & 0,562 & Valid \\
\hline & $\mathrm{X} 1.3$ & Mengingat slogan dan kampanye Aqua & 0,641 & Valid \\
\hline & $\mathrm{X} 1.4$ & Aqua memberikan manfaat sosial bagi masyarakat & 0,528 & Valid \\
\hline & $\mathrm{X} 1.5$ & Aqua memiliki keunggulan dari merek lain & 0,657 & Valid \\
\hline \multirow[t]{4}{*}{ Kesadaran Merek } & $\mathrm{X} 2.1$ & Mengetahuimerek Aqua & 0,519 & Valid \\
\hline & $\mathrm{X} 2.1$ & Mengenali logo Aqua & 0,721 & Valid \\
\hline & $\mathrm{X} 2.3$ & Mengenali a tribut Aqua & 0,625 & Valid \\
\hline & $\mathrm{X} 2.4$ & Menjadikan Aqua pilihan utama & 0,625 & Valid \\
\hline \multirow[t]{5}{*}{ Pemasaran digital } & $\mathrm{X} 3.1$ & Aqua menyediakan informasi lengkap pada website & 0,738 & Valid \\
\hline & $\mathrm{X} 3.2$ & Visibilitas Aqua padasearchengine & 0,646 & Valid \\
\hline & $\mathrm{X} 3.3$ & Promosi Aqua melalui web banner efektif & 0,720 & Valid \\
\hline & X3.4 & Komunikasi Aqua yang baik melalui media sosial & 0,693 & Valid \\
\hline & $\mathrm{X} 3.5$ & Program a filiasi marketing Aqua efektif & 0,732 & Valid \\
\hline Keputusan & Y1.1 & Berminat membeli AQUA sa at membutuhkan AMDK & 0,740 & Valid \\
\hline \multirow[t]{3}{*}{ Pembelian } & Y1.2 & Merekomendasikan Aqua & 0,731 & Valid \\
\hline & Y1.3 & Memilih Aqua dibandingkan merek lain & 0,770 & Valid \\
\hline & Y1.4 & Mencari informasi mengenai Aqua & 0,476 & Valid \\
\hline
\end{tabular}

Tabel 3. Hasil Uji Validitas

Sumber: Data diolah, 2021 
Hasil uji reliabilitas pada Tabel 4 menunjukkan nilai Cronbach's Alpha masing-masing variabel lebih besar dari 0,60. Hal tersebut menunjukkan bahwa seluruh variabel memiliki reliabilitas yang baik.

Tabel 4.

Hasil Uji Reliabilitas

\begin{tabular}{lcc}
\hline \multicolumn{1}{c}{ Variabel } & Cronbach's Alpha & Keterangan \\
\hline Merek Image (X1) & 0,760 & Reliabel \\
Merek Awareness (X2) & 0,780 & Reliabel \\
Pema saran digital(X3) & 0,798 & Reliabel \\
Keputusan pembelian (Y) & 0,800 & Reliabel \\
\hline
\end{tabular}

Sumber: Data diolah, 2021

Hasil analisis regresi linier berganda ditampilkan pada Tabel 5. H1 diterima dengan tingkat signifikansi $0,001<0,05$, berarti bahwa citra merek berpengaruh positif dan signifikan terhadap keputusan pembelian. $\mathrm{H} 2$ ditolak dengan tingkat signifikansi $0,114>0,05$, berarti bahwa kesadaran merek berpengaruh positif namun tidak signifikan terhadap keputusan pembelian. $\mathrm{H} 3$ diterima dengan tingkat signifikansi $0,006<0,05$, berarti bahwa pemasaran digital berpengaruh positif dan signifikan terhadap keputusan pembelian. Citra merek memiliki nilai koefisien regresi tertinggi diantara variabel lainnya, maka dapat disimpulkan bahwa citra merek berpengaruh peling dominan terhadap keputusan pembelian dibandingkan variabel lainnya dalam model. Nilai Adjusted R-Square dari model regresi adalah sebesar 0,477 yang bermakna bahwa citra merek, kesadaran merek, dan pemasaran digital mampu menjelaskan 47,7 \% variasi pada keputusan pembelian, sisanya sebesar 52,3\% dijelaskan oleh variabel lain yang tidak termasuk dalam model.

Tabel 5.

Hasil Uji Hipotesis

\begin{tabular}{lcccc}
\hline Model & $\mathbf{B}$ & Std.Error & $\mathbf{T}$ & Sig. \\
\cline { 2 - 3 } (Constant) & -2.096 & 1.948 & -1.067 & .285 \\
$\mathbf{X 1}$ & .433 & .132 & 3.293 & .001 \\
$\mathbf{X 2}$ & .205 & .128 & 1.597 & .114 \\
$\mathbf{X 3}$ & .256 & .090 & 2.832 & .006 \\
$\mathbf{R}^{2} \mathbf{. 0 , 4 7 7}$ & & & & \\
\hline
\end{tabular}

Sumber: Data diolah, 2021

Meningkatnya citra merek dapat mendorong minat konsumen membeli AMDK merek AQUA di kota Denpasar. Hasil penelitian ini sesuai dengan penelitian yang dilakukan oleh Yanti \& Sukotjo (2016) yang menemukan bahwa minat beli konsumen terhadap produk AMDK dipengaruhi secara signifikan oleh citra dari merk AMDK tersebut. Hasil penelitian Pulukadang et al. (2018) juga mendukung hasil penelitian ini yang menemukan bahwa persepsi citra merek yang semakin positif di benak konsumen mampu mendorong munculnya minat beli terhadap produk kesehatan. Fariha (2018) menemukan bahwa merek yang mudah dikenali dengan citra merek yang muda dan menyenangkan mampu mendorong minat beli secara signifikan pada konsumen muda. (Simamora \& Kusmiyati, 2017) menemukan bahwa produk pioneer dengan reputasi unggul menjadi salah satu faktor penting 
dalam mengambil keputusan pembelian. Untuk meningkatkan citra merek AQUA hal-hal yang dapat dilakukan adalah: menciptakan karakter produk yang khas mulai dari logo, slogan, desain produk sehingga memiliki identitas di mata konsumen, AQUA perlu menampilkan keunggulan produk dibandingkan dengan kompetitornya, AQUA dapat memberikan manfaat lebih bagi konsumen yaitu tidak hanya sebagai pelaku bisnis industri AMDK saja, namun dapat bermanfaat bagi lingkungan sosial.

Peningkatan kesadaran merek tidak mampu secara signifikan meningkatkan minat beli konsumen terhadap AQUA. Hasil penelitian ini tidak mendukung penelitian yang dilakukan oleh (Cahyani \& Sutrasmawati, 2016), (Ekawati \& Aryadirda, 2015), (Sudarso, 2018), (Ghealita, 2015), dan (Apriliya, 2018) yang menemukan bahwa kesadaran merek berpengaruh secara positif dan signifikan terhadap keputusan pembelian. Dalam penelitian ini kesadaran merek menunjukan pengaruh yang tidak signifikan diduga karena mayoritas responden penelitian berasal dari kalangan mahasiswa dan juga pelajar yang belum mandiri secara finansial, sehingga perilaku konsumsi mereka cenderung berhemat atau membeli produk yang lebih terjangkau. Walaupun responden telah mengenal merek AQUA, hal tersebut tidak mendorong responden untuk melakukan pembelian, karena mereka cenderung memilih merek yang lebih murah karena alasan finansial.

Meningkatnya aktivitas pemasaran digital dapat mendorong minat konsumen membeli air mineral dalam kemasan merek AQUA di kota Denpasar. Hasil penelitian ini didukung oleh sejumlah penelitian yaitu: Saputra \& Ardani (2020) yang menemukan bahwa pengenalan dan promosi produk yang dilakukan di media online mampu meningkatkan minat beli konsumen; Batu et al. (2019) menemukan bahwa aktivitas pemasaran digital seperti pemasaran sosial media, affiliate marketing, dan email marketing mempengaruhi keputusan pembelian secara signifikan; Mewoh et al. (2019) menemukan bahwa aktivitas ecommerce yang dilakukan oleh peritel mampu meningkatkan minat beli konsumen; dan Pratama (2017) menemukan bahwa penggunaan platform online untuk aktivitas informasi, promosi, dan transaksi meningkatkan minat beli konsumen secara signifikan. Untuk meningkatkan aktivitas pemasaran digital, hal-hal yang perlu dilakukan adalah menyediakan informasi yang lengkap pada website resmi AQUA, meningkatkan visibilitas AQUA pada search engine, menjalin hubungan yang interaktif dengan konsumen melalui media sosial, bekerja sama dengan perusahaan lain (affiliate marketing) dalam memasarkan AQUA.

\section{SIMPULAN DAN SARAN}

Hasil penelitian menunjukan bahwa variabel citra merek dan pemasaran digital berpengaruh positif dan signifikan terhadap keputusan pembelian. Namun variabel kesadaran merek berpengaruh positif namun tidak signifikan terhadap keputusan pembelian. Untuk mendorong keputusan pembelian konsumen, AQUA perlu meningkatkan kinerjanya pada beberapa variabel yaitu: variabel citra merek dengan menciptakan karakter produk yang khas mulai dari logo, slogan, desain produk, menampilkan keunggulan produk, dan memberikan manfaat lebih bagi konsumen di berbagai aspek. Pada variabel kesadaran merek AQUA perlu meningkatkan kesadaran konsumen terhadap merek AQUA sehingga produk ini dapat menjadi top of mind dalam benak konsumen. Pada variabel pemasaran digital hal-hal yang perlu dilakukan adalah menyediakan informasi yang lengkap pada website resmi AQUA, meningkatkan visibilitas pada search engine, menjalin hubungan interaktif melalui media sosial, dan melakukan affiliate marketing.

Keterbatasan penelitian ini adalah terbatasnya generalisasi hasil penelitian di industri lain sebab karakteristik unik dari industri dapat mengubah serangkaian faktor yang mempengaruhi keputusan pembelian konsumen. Bagi penelitian selanjutnya diharapkan mampu menambahkan 
variabel yang dapat mempengaruhi keputusan pembelian yaitu harga, kualitas produk, word of mouth, serta menambahkan variabel mediasi seperti sikap konsumen, serta memperluas ruang lingkup penelitian sehingga memberikan gambaran yang lebih komprehensif.

\section{REFERENSI}

Andrian. 2016. Pengaruh Digital Marketing Dan Ragam Produk Terhadap Minat Beli Konsumen Toko Online SHOPEE. Jurnal Bisnis dan Manajemen, 3(1), 14-24.

Batu, R.L., Situngkir, L.T., Krisnawati, I., \& Halim, S. 2018. Penga ruh Digital Marketing Terha dap Online Purcha se Decision Pada Platform Belanja Online Shopee. Jurnal Ekonomi \& Bisnis, 18(2), 144-152.

Cahyanti K.I, \& Sutra smawati.E. 2016. Pengaruh Merek Awareness Dan Merek Image Terhadap Ke put usan Pembelian. Management Analyisis Journal, 5(1), 81-288.

Ekawati, S. \& Aryadirda, Y.2015. Pengaruh Merek Awareness Dan Kualitas Produk Terhadap Ke put usan Pembelian Produk Pla net Popcorn Pa da Mahasiswa Fakultas Ekonomi Universit as Tarumanegara Jakarta. JurnalEkonomi, 20(3), 414-427.

Fariha, R. 2018. "Pengaruh Merek Image Terhadap Keputusan Pembelian Produk Minuman Franchise Chatime Pada Remaja Di Kota Palembang". (Skripsi). Palembang: Politeknik Negeri Sriwija ya.

Fure, F., Lapian, J., \& Teroreh, R. 2015. Pengaruh Merek Image, Kualitas Produk, dan Harga Terhadap Keputusan Pembelian J.Co Manado. Jurnal EMBA, 3(1), 367-377.

Ghealita, V., \& Setyorini, R. 2015. Pengaruh Merek Awareness Terhadap Keputusan AMDK Merek AQUA Di Kota Bandung. Jurnal Manajemen Bisnis Telekomunikasi dan Informatika, 6(1), 1-9.

Indiani, N.L.P, \& Fahik, G.A. 2020. Conversion of online purchase intention into actual purchase: the moderating role of transaction security and convenience. Business: Theoryand Practice, 21(1), 18-29.

Info Merek. 2020. Eksistensi Air Minum Dalam Kemasan, AQUA Pegang Kendali. Available at: https://infomerek.id/eksistensi-air-minum-dalam-kemasan-di-ranah-digital-aqua-pegang kendali.phtml.Accessed September.2020

Kotler,P., \& Keller, K.L. 2008. Manajemen Pemasaran. Jilid 1. Edisi Kedua Belas. Jakarta:Erla ngga.

Linggar, A. (2016). Pengaruh Word of Mouth, Kesa daran Merekdan Kualitas Produk Terhadap Ke putu san Pembelian Mie Akhirat Di Surabaya. Jurnal Bisnis dan Manajemen, 8(2), 237-252.

Mewoh, F.M., Jhony, R. E. T, \& Mukuan, S. D.D. 2019. Penga ruh Digital Marketing Terhadap Keputusan Pembelian Pada Matahari Departement Store Manado Town Square. Jurnal Administrasi Bisnis, 9(1), $35-42$.

Peter, J. P., \& Jerry C.O. 2000. Consumer Behavior. Perilaku konsumen dan Strategi Pemasaran. Jilid 2. Edisi 4. Jakarta: Erlangga.

Pratama, I.M. 2017. “Pengaruh Digita lMarketing dan Merek Awa reness Terhadap Keputusan Pembe lian Di Tokopedia". (Skrpsi). Bandung: Universitas Widyatama.

Pulukadang, M.W., Mananeke, L., \& Roring, F. 2018. Pengaruh Merek Image Terhadap Keputusan Pembelian Produk Herbalife. JurnalEMBA, 6(3), 1608-1617.

Rahman, A. 2010. Panduan Pelaksanaan administrasi Perpajakan untuk Karyawan, Pelaku Bisnis, dan Perusahaan. Bandung: Nuansa.

Ronoprasetyo, T. 2018. "Pengaruh Word Of Mouth Dan Merek Awareness Terhadap Keputusan Pembelia n (Studi Ka sus Pa da Bjong NgopiDi Sleman)". (Skripsi). Yogyakarta: Universitas Negeri Yogya karta.

Sam, H. (2018). Digital Marketing pengertian menurut para ahli \& manfaat kelebihankekurangan".https://www.dosenpendidikan.com/digital-marketing-p engertian -menuru t-para-ahlimanfaat-kelebihan-kekurangan/ (diakses pada 12 November 2018)

Saputra.G.W., \& Ardani.I.G.A.S.K. 2020. Pengaruh Digital Marketing Word Of Mouth Dan Kualitas Pela yanan Terhadap Keputusan Pembelian. E-JumalManajemen, 9(7), 2596-2620.

Simamora V. \& Kusmiyati, E. 2017. Pengaruh Desain Produk Dan Merek Image Terhadap Keputusan Pembelian Pada Teh Botol Sosro Dengan Kualitas Produk Sebagai Va ria bel Moderatring. Jurnal Online Internasional dan Nasional, 20(1), 43-54.

Suciningtyas, W. 2012. Penga ruh Merek Awareness, Merek Image dan Media Communication Terhadap Keputusan Pembelian. Manajemen Analysis Journal, 1(1).1-14.

Sudarso, A., \& Maryani, E. 2016. Pengaruh Kesadaran Merek dan Promosi Terhadap Keputu san Kon sumen Untuk MembeliDiCV. Panda Bakery. Jurnal Manajemen, 1(1), 1-11.

Sugiyono. 2015. Metode Penelitian Kuantitatif, Kualitatif, dan R\&D, Cetakanke-22. Bandung: Alfa beta.

Surachman. 2008. Da sar-Dasar Pemasaran (AlatPemasaran Untuk Memenangkan Persaingan). Malang: B ay u Media Publishing.

$\overline{\text { Pengaruh Citra Merek, Kesadaran Merek, Dan Pemasaran Digital Terhadap Keputusan Pembelian Amdk Aqua, }}$ Anak Agung Inta Setya Dewidan Ni Luh Putu Indiani 
Top Merek Award. 2020. Top Merek Indeks. Available at: https://www.topmerek -award.com/top-merekindex/?tbi_find=aqua (accessed September 2020).

Yanti.M.Z., \& Sukotjo. H. 2016.Pengaruh Kesadaran Merek, Asosiasi Merek, dan Merek Image Terhadap Keputusan Pembelian AQUA. Jurnal Ilmu dan Riset Manajemen, 5(5), 2-15. 